\title{
Simulation of long-range transport aerosols from the Asian Continent to Taiwan by a Southward Asian high-pressure system
}

\author{
Ming-Tung Chuang ${ }^{a}$, Joshua S. Fu ${ }^{b}$, Carey J. Jang ${ }^{c}$, Chang-Chuan Chan ${ }^{d}$, \\ Pei-Cheng Ni ${ }^{e}$, Chung-Te. Lee ${ }^{a, *}$ \\ ${ }^{a}$ Graduate Institute of Environmental Engineering, National Central University Jhongli, Taoyuan, Taiwan \\ ${ }^{\mathrm{b}}$ Department of Civil and Environmental Engineering, University of Tennessee, Knoxville, Tennessee, USA \\ 'Office of Air Quality Planning and Standards, United States Environmental Protection Agency, USA \\ ${ }^{\mathrm{d}}$ Institute of Occupational Medicine and Industrial Hygiene, National Taiwan University, Taipei, Taiwan \\ ${ }^{\mathrm{e}}$ CTCI Corporation, Taipei, Taiwan
}

\section{A R T I C L E I N F O}

\section{Article history:}

Received 16 February 2008

Received in revised form 26 June 2008

Accepted 2 July 2008

Available online 14 September 2008

\section{Keywords:}

Long-range transport

Atmospheric aerosol

MM5

CMAQ

Taipei Aerosol supersite

\begin{abstract}
A B S T R A C T
Aerosol is frequently transported by a southward high-pressure system from the Asian Continent to Taiwan and had been recorded a $100 \%$ increase in mass level compared to nonevent days from 2002 to 2005. During this time period, $\mathrm{PM}_{2.5}$ sulfate was found to increase as high as $155 \%$ on event days as compared to non-event days.

In this study, Asian emission estimations, Taiwan Emission Database System (TEDS), and meteorological simulation results from the fifth-generation Mesoscale Model (MM5) were used as inputs for the Community Multiscale Air Quality (CMAQ) model to simulate a long-range transport of $\mathrm{PM}_{2.5}$ event in a southward high-pressure system from the Asian Continent to Taiwan. The simulation on aerosol mass level and the associated aerosol components were found within a reasonable accuracy. During the transport process, the percentage of semi-volatile $\mathrm{PM}_{2.5}$ organic carbon in $\mathrm{PM}_{2.5}$ plume only slightly decreased from $22-24 \%$ in Shanghai to $21 \%$ near Taiwan. However, the percentage of $\mathrm{PM}_{2.5}$ nitrate in $\mathrm{PM}_{2.5}$ decreased from $16-25 \%$ to $1 \%$. In contrast, the percentage of $\mathrm{PM}_{2.5}$ sulfate in $\mathrm{PM}_{2.5}$ increased from $16-19 \%$ to $35 \%$. It is interesting to note that the percentage of $\mathrm{PM}_{2.5}$ ammonium and $\mathrm{PM}_{2.5}$ elemental carbon in $\mathrm{PM}_{2.5}$ remained nearly constant.

Simulation results revealed that transported pollutants dominate the air quality in Taipei when the southward high-pressure system moved to Taiwan. Such condition demonstrates the dynamic chemical transformation of pollutants during the transport process from continental origin over the sea area and to the downwind land.
\end{abstract}

(c) 2008 Elsevier B.V. All rights reserved.

\section{Introduction}

In the last decade, China has been experiencing substantial economical growth. The establishment of numerous industrial parks and the dramatic increase of vehicles in urban areas were indicative of such economic boom (Hao and Wang, 2005). In particular, industrial and transport development cause pollutant emissions to rise significantly and worsen the air quality in urban cities (Chan et al., 2005). Among the emitted pollutants, sulfur dioxide from the burning of fossil fuel is

\footnotetext{
* Corresponding author. Graduate Institute of Environmental Engineering, National Central University No.300, Jhongda Rd., Jhongli City, Taoyuan County 32001, Taiwan. Tel.: +886 34227151x34657; fax: +886 34221602.

E-mail address: ctlee@cc.ncu.edu.tw (C.-T. Lee).
} 
noted to cause acid deposition in the downwind areas. Increased sulfuric emissions from China affect its neighboring countries through a long-range transport process in the atmosphere (Kitada and Tanaka, 1992; Chung et al., 1996; Lin et al., 2005). The thrust of long-range transport of China's outflow is the Asian high-pressure system that originated from Siberia moving eastwardly or southwardly. In the past few years, there have been several publications that observed and estimated the contribution of acid deposition from China to downwind areas on a level of 20 to 50\% (Kitada and Tanaka, 1992; Ichikawa and Fujita, 1995; Chung et al., 1996; Chang et al., 2000; Holloway et al., 2002).

The study of long-range transport has emerged in the last decades at different places. In Europe, Borge et al. (2007) used the method of two-stage backward trajectory and found that the nonattainment of $\mathrm{PM}_{10}$ in Madrid (Spain) and Birmingham (UK) was highly related to long-range transport from North Africa and continental Europe. Koçak et al. (2007) showed that the high level of $\mathrm{PM}_{10}$ on the coast of the Eastern Mediterranean during the transition period was mainly contributed by the long-range transport from North Africa. Grivas et al. (2008) also found a notable part of $\mathrm{PM}_{10}$ events could be attributed to long-range transport originating from Sahara desert and the Western Mediterranean. While in the United States, there is trans-boundary ozone problem across the Eastern United States (Farrell and Keating, 2002) and acid deposition of longrange transport damaging the national parks in the Western United States (Hageman et al., 2006). Even the anthropogenic emissions in Asia had been modelled to impact the air quality of the North Western United States through long-range transport (Berntsen et al., 1999). Focus on the long-range transport from the Asian Continent is highlighted in the last few years and continues to be investigated. It had been reported that yellow dust originating from China and Inner Mongolia carried pollutants along the transport path to the downwind areas (Carmichael et al., 1995; Nishikawa et al., 2000; Han et al., 2004; Lee et al., 2006). From size-resolved aerosol chemical components observed in Hong Kong, Zhuang et al. (1999a) pointed out that the reactions of $\mathrm{H}_{2} \mathrm{SO}_{4}$ and $\mathrm{HNO}_{3}$ with $\mathrm{CaCO}_{3}$ formed sulfate and nitrate in coarse particles. The surface of dust particles provides deposition and reaction sites for $\mathrm{SO}_{2}$ and $\mathrm{NO}_{\mathrm{X}}$. Shimohara et al. (2001) sampled gases and particles in Goto Island in Japan; they found that aerosol acidity was influenced by $\mathrm{NH}_{4} \mathrm{HSO}_{4}$ in particles. Besides, they found that the main compound forms of nitrate are $\mathrm{NaNO}_{3}$ and $\mathrm{Ca}\left(\mathrm{NO}_{3}\right)_{2}$, respectively. These two chemicals were formed by gaseous $\mathrm{HNO}_{3}$ reacting with either $\mathrm{NaCl}$ or $\mathrm{CaCO}_{3}$. Kim and Park (2001) found that the major water-soluble ions in the transported aerosols are $\mathrm{SO}_{4}^{2-}, \mathrm{NO}_{3}^{-}, \mathrm{Ca}^{2+}$, and $\mathrm{Na}^{+}$, implying that Asian dust storm transported both urban and industrial pollutants to the downwind Western Pacific countries. Yellow dust had been reported to transport to Taiwan for many years (Lin, 2001; Wang et al., 2004; Lin et al., 2005; Lee et al., 2006; Liu et al., 2006). Lin et al. (2005) further explained that the longrange transport of yellow dust to Taiwan was usually accompanied by a cold frontal system.

In the past, the characteristic of yellow-dust events is noted by the sharp increase of coarse particles only. However, Lee et al. (2006) observed that $\mathrm{PM}_{2.5}$ (particles with an aerodynamic diameter less than or equal to $2.5 \mu \mathrm{m}$ ) and
$\mathrm{PM}_{2.5}$ sulfate both increased in the dust event that occurred on 6 March 2002. This implies that fine particles were also transported with the movement of the high-pressure system in the yellow-dust event. In Taiwan, yellow-dust event had been shown to cause health detriments on people. According to the statistical data gathered by Chan et al. (2000), the number of people that went to hospitals was increased with the arrival of yellow dust, lasting for three or four days. In addition, Chan et al. (2000) found that yellow dust might aggravate the illness of patients with cardiovascular or respiratory diseases. Indeed, from the survey of epidemiology, human mortality is highly related to the exposure of $\mathrm{PM}_{2.5}$ (Schwartz et al., 1996; Harrison and Yin, 2000; Kennedy and Hinds, 2002). Consequently, the study of the long-range transport of $\mathrm{PM}_{2.5}$ for the evolution of aerosol components during the transport is worthwhile. In light of the above, the purpose of this study is to therefore utilize an air quality model to simulate the transport of $\mathrm{PM}_{2.5}$ and its components varied during the process from the Asian Continent to Taiwan. The success of this model simulation will help in obtaining more insights of chemical transformation between gases and aerosol species in long-range transport by the southward high-pressure system.

\section{Study area and monitoring of data}

Fig. 1 shows that Taiwan is geographically located in the Western Pacific Ocean with the $200 \mathrm{~km}$-wide Taiwan Strait separating the territory from the rest of the Asian Continent. During cold seasons (autumn, winter, spring), the Asian highpressure system mainly push the air masses passing over China and other countries in the Western Pacific Ocean. When this occurs, the prevailing wind direction in Taiwan is mainly from the northeast. The greater Taipei area, located in northern Taiwan, is the first place influenced by long-range transport originating from the Mainland.

The aerosol observation data used in this study were collected at the Taipei supersite (TAS, \#1 in Fig. 1). TAS is the first site that monitors chemical components and the optical characteristics of aerosol continuously in Taiwan (details see Lee et al. (2006)). Except for aerosol observations at the TAS site, $\mathrm{PM}_{2.5}$ monitoring data from nearby air quality monitoring sites (KT: \#2; KL: \#3; WL: \#4, Fig. 1) were also analyzed. To account for the different aerosol and meteorological characteristics in this study, wind and pressure observations were averaged from the TPE (\#5, Fig. 1) and PJY (\#6, Fig. 1) meteorological sites that are located in the Taipei city center and $56 \mathrm{~km}$ off-coastline, respectively. Furthermore, the weather maps adopted in this study were sourced from the Japan Meteorology Agency or JMA (http://www.jma.go.jp/ jp/g3/).

\section{Model description and setup}

The study utilized the fifth-generation Pennsylvania State University-National Center for Atmospheric Research Mesoscale Model (MM5, Grell et al., 1994) to generate meteorological data as an input for chemical model. Four simulation domains 


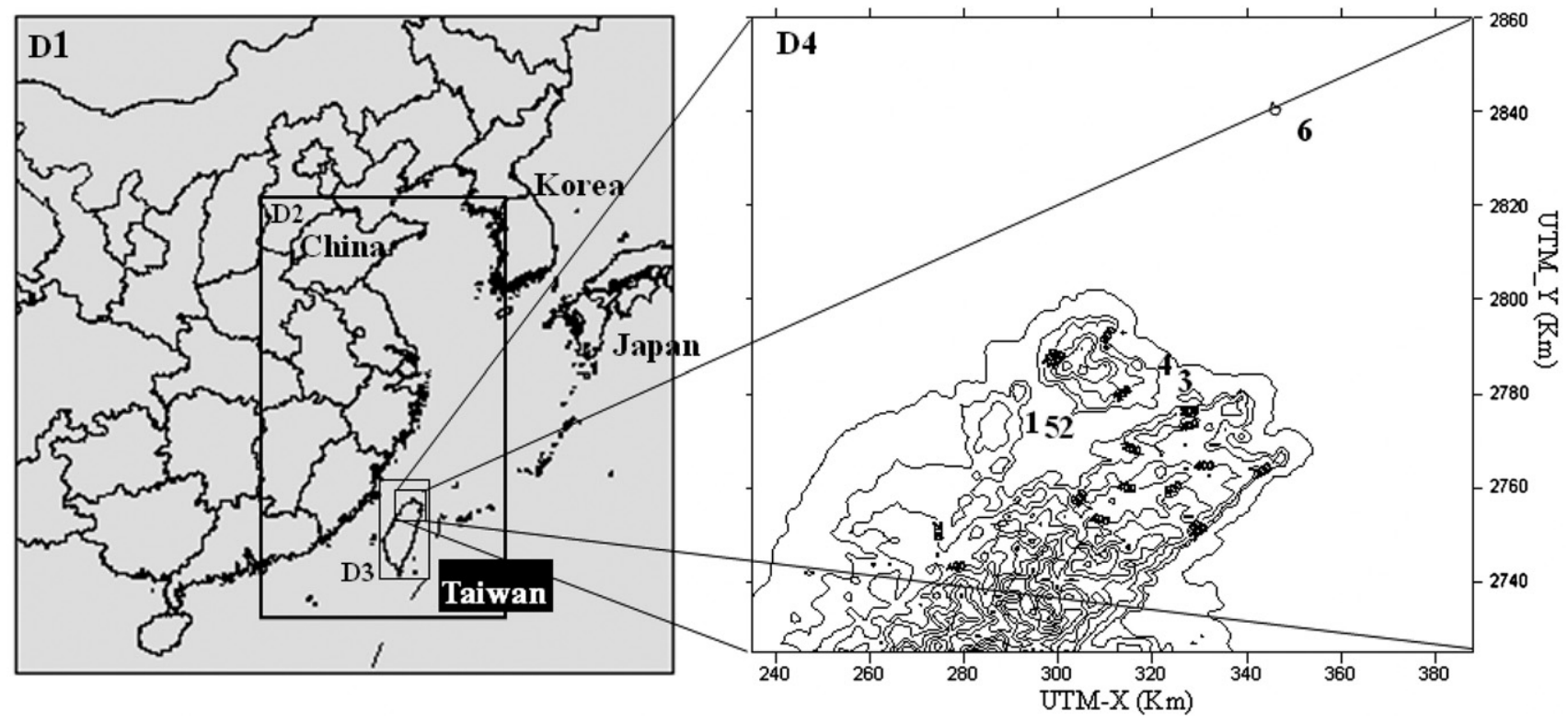

Fig. 1-Model simulation domains (D1 to D4) and geographical locations of the air quality monitoring sites (1: the TAS site, Taipei aerosol supersite; 2: the KT site; 3: the KL site; 4: the WL site), and meteorological sites (5: the TPE site; 6: the PJY site).

were set up for the study (Fig. 1). Horizontal resolutions were at $36,12,4$, and $1.33 \mathrm{~km}$ for each domain, respectively. The initial and boundary conditions for meteorological modeling were from the National Centers for Environmental Prediction or NCEP (http://www.ncep.noaa.gov/). For cumulus-cloud and moisture schemes, Grell cumulus scheme (Grell et al., 1994) and mixed-phase option were used for the first three larger domains, and non-cumulus parameterization and dry option were used for the fourth domain. For boundary layer parameterization, all domains adopted a Blackadar scheme in this study.

For the chemical model, this study used Models-3 Community Multiscale Air Quality (CMAQ version 4.4, Byun and Ching, 1999) modeling system. In order to shorten the computation time and reduce the size of output files, the 25layer output of the meteorological model was transformed into 14 layers as inputs for the CMAQ. The layers were still intense near surface, and the $\sigma$ coordinate of the lowest layer was at 0.995 , which is equivalent to $38 \mathrm{~m}$ above ground. The CB-IV gasphase mechanism (Gery et al., 1989), the third generation CMAQ aerosol mechanism, and aqueous/cloud chemistry (cb4_ae3_aq) options were chosen for chemical mechanism.

The emission data of domain 1 and domain 2 were based on Streets et al. (2003). In order to reflect the rapid economic growth in China in the last few years, the researchers estimated the anthropogenic growth factors from 2001 to 2004 using the results of the similar studies of Hao and Wang (2005) and Heo and Feng (2005). Specifically, the yearly emission growth factors of 1.13 and 1.19 were adopted in this study for 2001 to 2003 and 2003 to 2004 , respectively.

Meantime, biogenic sources were assumed to remain constant. Emissions of domain 3 and domain 4 were taken from TEDS 6.1 (Taiwan Emission Database System 2003, Fu et al., in press; TWEPA, 2006a). The temporal and spatial distributions of source emissions were referred from TWEPA (2006a) and were transferred through the use of SMOKE (version 2.1, Houyoux and Vukovich, 1999) to estimate the grid/hourly emissions in Taiwan for 2003. The researchers noted that TEDS 6.1 is the only official emission database available in Taiwan. They likewise decided to use the estimated 2003 emissions for their modeling exercises for 2004 scenarios as the economic growth during these two years varied little in Taiwan.

\section{Results and discussion}

4.1. Observation of aerosol mass concentration at the Taipei aerosol supersite

The results of Chuang et al.'s (2008) study show that based on three years' statistics, aerosol concentrations in Taipei increased dramatically under strong northeast wind as the leading edge of high-pressure system from the Asian Continent moved rapidly in the territory. In their study, they defined this type of episodical weather pattern as HPP (Highpressure Pushing Pattern) and observed 53 HPP events in total of 354 aerosol events from March 2002 to February 2005. For HPP event days, hourly $\mathrm{PM}_{2.5}$ and $\mathrm{PM}_{2.5}$ sulfate concentrations were 54.1 and $12.0 \mathrm{\mu g} \mathrm{m}^{-3}$, respectively, higher than 22.6 and $4.7 \mu \mathrm{g} \mathrm{m}^{-3}$ observed on non-HPP days (Table 1 ). Although the difference between HPP and non-HPP days for $\mathrm{PM}_{2.5}$ nitrate and $\mathrm{PM}_{2.5}$ OC was not as much as $\mathrm{PM}_{2.5}$ sulfate, $\mathrm{PM}_{2.5}$ nitrate and $\mathrm{PM}_{2.5}$ OC during HPP event days were still 86 and 29\% higher than those on non-HPP days, respectively. Among these aerosol components, $\mathrm{PM}_{2.5}$ EC was found to have nearly no difference between HPP event and non-HPP days. Meteorology results indicate that the prevailing wind direction was either strong east or northeast wind on HPP event days. Meanwhile, wind direction was varied on non-HPP days. Furthermore, surface pressure on HPP event days in the Taipei basin was 
Table 1 - Basic statistics of aerosol components and weather parameters for high-pressure pushing (HPP) weather pattern and non-HPP time periods

\begin{tabular}{|c|c|c|c|c|c|c|c|}
\hline Station & Monitoring item & Weather pattern & Effective hours & Avg. & S.D. & Max. & Min. \\
\hline \multirow[t]{5}{*}{ TAS } & $\mathrm{PM}_{2.5}\left(\mu \mathrm{g} \mathrm{m}^{-3}\right)$ & $\mathrm{HPP}$ & 937 & 54.1 & 23.8 & 148.3 & 6.5 \\
\hline & $\mathrm{PM}_{2.5}$ sulfate $\left(\mu \mathrm{g} \mathrm{m}^{-3}\right)$ & HPP & 819 & 12.0 & 7.2 & 55.1 & 1.3 \\
\hline & $\mathrm{PM}_{2.5}$ nitrate $\left(\mu \mathrm{g} \mathrm{m}^{-3}\right)$ & HPP & 806 & 2.6 & 2.0 & 14.9 & 0.4 \\
\hline & $\mathrm{PM}_{2.5} \mathrm{OC}\left(\mu \mathrm{g} \mathrm{m}^{-3}\right)$ & HPP & 803 & 4.5 & 1.0 & 13.9 & 1.0 \\
\hline & $\mathrm{PM}_{2.5}$ EC $\left(\mu \mathrm{g} \mathrm{m}^{-3}\right)$ & HPP & 524 & 1.7 & 0.8 & 8.6 & 1.0 \\
\hline \multirow[t]{3}{*}{ TPE } & Wind speed $\left(\mathrm{m} \mathrm{s}^{-1}\right)$ & HPP & 991 & 3.8 & 1.2 & 7.9 & 2.0 \\
\hline & Wind direction (degree) & HPP & 991 & 87 & 31 & - & - \\
\hline & Surface pressure (mb) & HPP & 991 & 1020.1 & 5.4 & 1031.2 & 1007.1 \\
\hline \multirow[t]{3}{*}{ PJY } & Wind speed $\left(\mathrm{m} \mathrm{s}^{-1}\right)$ & HPP & 1248 & 7.2 & 2.2 & 15.2 & 2.1 \\
\hline & Wind direction (degree) & HPP & 1248 & 39 & 33 & - & - \\
\hline & Surface pressure (mb) & HPP & 1248 & 1021.9 & 5.0 & 1032.8 & 1009.5 \\
\hline \multirow[t]{5}{*}{ TAS } & $\mathrm{PM}_{2.5}\left(\mu \mathrm{g} \mathrm{m}^{-3}\right)$ & non-HPP* & 8250 & 22.6 & 11.4 & 64.5 & 5.0 \\
\hline & $\mathrm{PM}_{2.5}$ sulfate $\left(\mu \mathrm{g} \mathrm{m}^{-3}\right)$ & non-HPP* & 7662 & 4.7 & 3.5 & 28.5 & 0.4 \\
\hline & $\mathrm{PM}_{2.5}$ nitrate $\left(\mu \mathrm{g} \mathrm{m}^{-3}\right)$ & non-HPP* & 6717 & 1.4 & 1.1 & 20.2 & 0.4 \\
\hline & $\mathrm{PM}_{2.5} \mathrm{OC}\left(\mu \mathrm{g} \mathrm{m}^{-3}\right)$ & non-HPP* & 6747 & 3.5 & 1.7 & 18.0 & 1.0 \\
\hline & $\mathrm{PM}_{2.5} \mathrm{EC}\left(\mu \mathrm{g} \mathrm{m}^{-3}\right)$ & non-HPP ${ }^{*}$ & 2142 & 1.7 & 1.2 & 13.9 & 1.0 \\
\hline \multirow[t]{3}{*}{ TPE } & Wind speed $\left(\mathrm{m} \mathrm{s}^{-1}\right)$ & non-HPP* & 9093 & 3.8 & 1.2 & 12.1 & 2.0 \\
\hline & Wind direction (degree) & non-HPP* & 9093 & - & - & - & - \\
\hline & Surface pressure (mb) & non-HPP* & 9093 & 1017.2 & 5.9 & 1033.8 & 989.9 \\
\hline \multirow[t]{3}{*}{ PJY } & Wind speed $\left(\mathrm{m} \mathrm{s}^{-1}\right)$ & non-HPP* & 12482 & 7.7 & 2.9 & 37.3 & 2.0 \\
\hline & Wind direction (degree) & non-HPP* & 12482 & - & - & - & - \\
\hline & Surface pressure (mb) & non-HPP* & 12482 & 1018.4 & 6.0 & 1036.0 & 990.4 \\
\hline
\end{tabular}

*Non-HPP time period is for days excluding June, July, August, and the characterstics of HPP weather pattern is defined in Chuang et al. (2008).

3 millibar higher than that on non-HPP days, which indicates the arrival of the Asian high-pressure system.

\subsection{Model simulation of aerosol episode peaked on 20 December 2004}

One of the typical HPP events occurred on 20 December 2004, which this study selected for model simulation due to its relative abundance of data availability for comparison with simulation results. The simulated near-surface level $\mathrm{PM}_{2.5}$ contour and the associated weather maps are shown in Fig. 2. At 08:00 (local time and thereafter) of December 19th, there was a cold front formed around Shandong province in China (Fig. 2(a)). Six hours later, the cold front gradually moved eastwardly and arrived at Bo Hai Sea. Meanwhile, the air mass with high $\mathrm{PM}_{2.5}$ concentration (also called $\mathrm{PM}_{2.5}$ plume in the following text) was pushed eastwardly (Fig. 2(b)) by the frontal system and reached Jiangsu province. The researchers noted that prefrontal and postfrontal $\mathrm{PM}_{2.5}$ plumes were not split by the cold front even though they were located in warm and cold air masses, respectively. In other words, there was no differentiation between these two $\mathrm{PM}_{2.5}$ plumes that can be found from modelling results. When the low pressure center of the cold front moved to the east of Korea (Fig. 2(c)), the prefrontal $\mathrm{PM}_{2.5}$ plume moved to the East China Sea. The $\mathrm{PM}_{2.5}$ level began to drop due to the dilution of clean ocean air, and the plume was far away from the source area (Fig. 2(d)). The $\mathrm{PM}_{2.5}$ plume then began to move southwardly along the peripheral circulation of the postfrontal high-pressure system. At 08:00 of December 20th, $\mathrm{PM}_{2.5}$ plume began to influence northern Taiwan (Fig. 2(e)). In Fig. 2(e), the $\mathrm{PM}_{2.5}$ level in the plume on the waters around northern Taiwan was about $70 \mu \mathrm{g}$ $\mathrm{m}^{-3}$. According to the records of the 12 air-quality monitoring sites in the Taipei area (http://taqm.epa.gov.tw/emc/default. aspx?mod=PsiAreaHourly), the $\mathrm{PM}_{10}$ concentrations in the area were around or even above $100 \mu \mathrm{g} \mathrm{m}^{-3}$. These results indicate that long-range transport aerosol dominated the aerosol level for the whole Taipei basin during this period. The high $\mathrm{PM}_{2.5}$ plume was apparently pushed by the Asian continental high-pressure ridge when it stretched to Taiwan (Fig. 2(g)). After reaching Taiwan, due to the blocking of mountains in Northern Taiwan, $\mathrm{PM}_{2.5}$ plume began to skirt around each side of Taiwan and caused $\mathrm{PM}_{2.5}$ level to decrease (Fig. 2(h)).

\subsection{Comparison of aerosol properties between observation and model simulation}

Fig. 3(a) to (d) show that $\mathrm{PM}_{2.5}$ plume actually began to influence the Taipei air quality at 04:00 of December 20th. However, the simulated $\mathrm{PM}_{2.5}$ plume was delayed for four hours to influence the Taipei air quality at 08:00 of the same day. The delay could be attributed to the error associated with meteorological modelling from the comparison of simulated and observed wind speeds and wind directions, which could be used to signify the arrival of a high pressure system (not shown). From Fig. 3(a) to (d), it was clear that both simulated and observed $\mathrm{PM}_{2.5}$ concentrations at the TAS (\#1, Fig. 1), KT (\#2, Fig. 1), KL (\#3, Fig. 1), and WL (\#4, Fig. 1) sites located inside or outside the Taipei basin had similar variation cycles and peaked at 70-73 $\mu \mathrm{g} \mathrm{m}^{-3}$. The researcher also noted that $\mathrm{PM}_{2.5}$ level, $\mathrm{PM}_{2.5}$ sulfate, $\mathrm{PM}_{2.5}$ nitrate, and $\mathrm{PM}_{2.5}$ carbons were monitored by different instruments at the TAS site (details are in Lee et al., 2006). Fig. 3(e) shows that the simulated and observed $\mathrm{PM}_{2.5}$ sulfate concentrations were very close to each other. The synchronized moving of $\mathrm{PM}_{2.5}$ with the air mass 
(a)
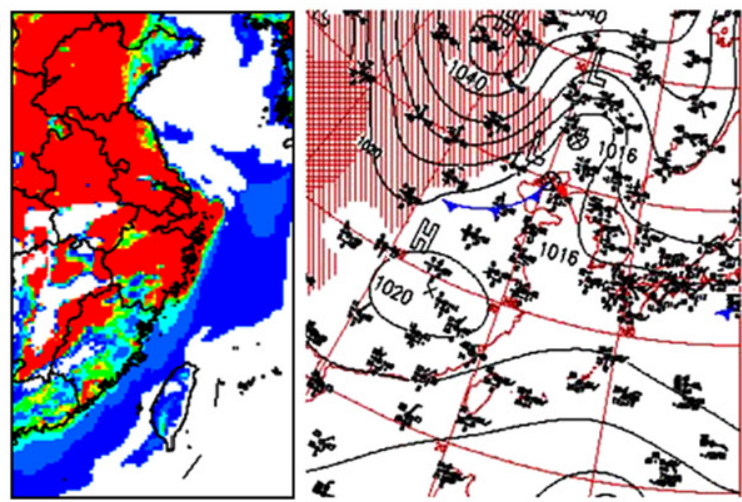

(c)

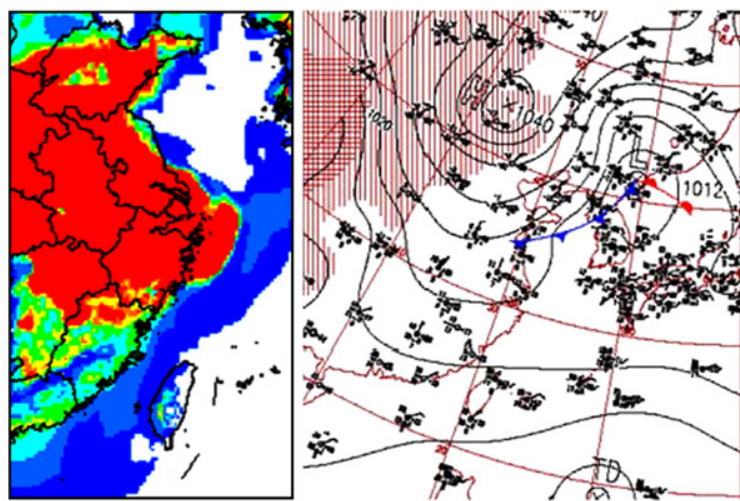

(e)
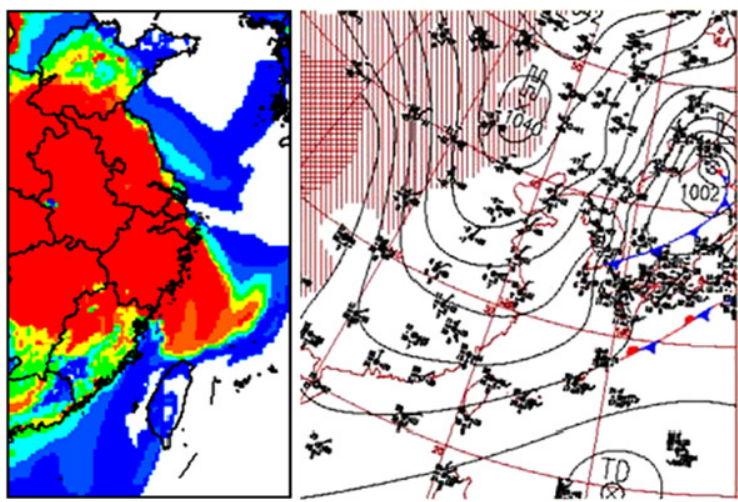

(g)
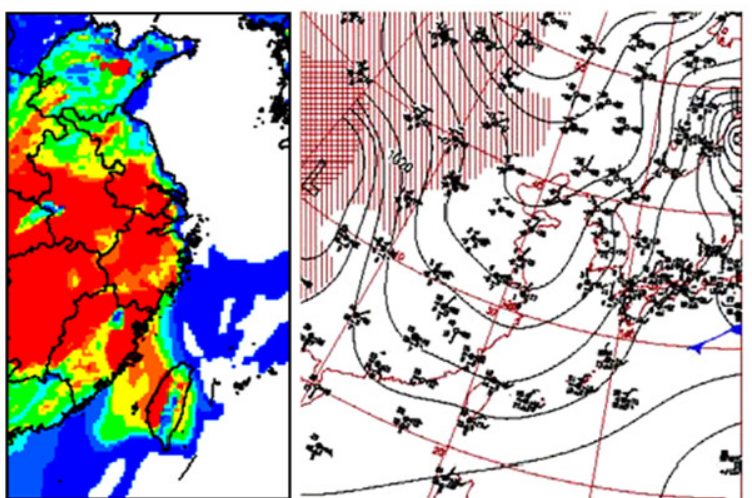

(b)
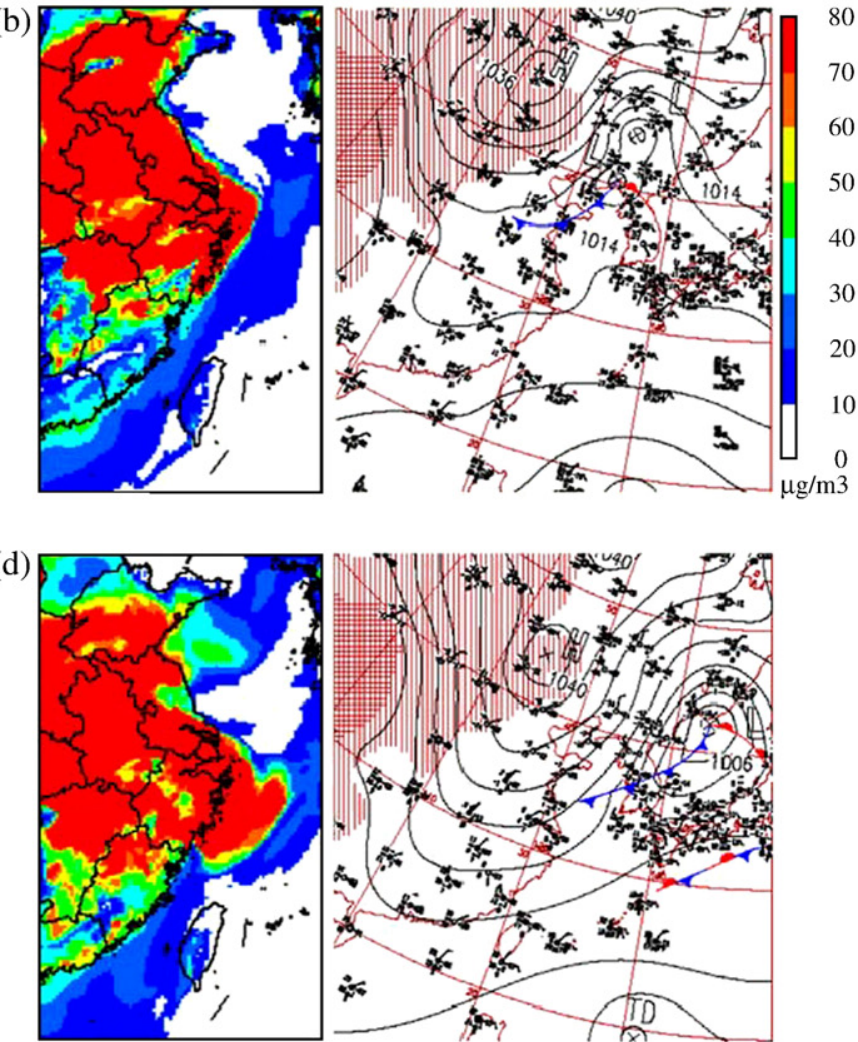

(f)
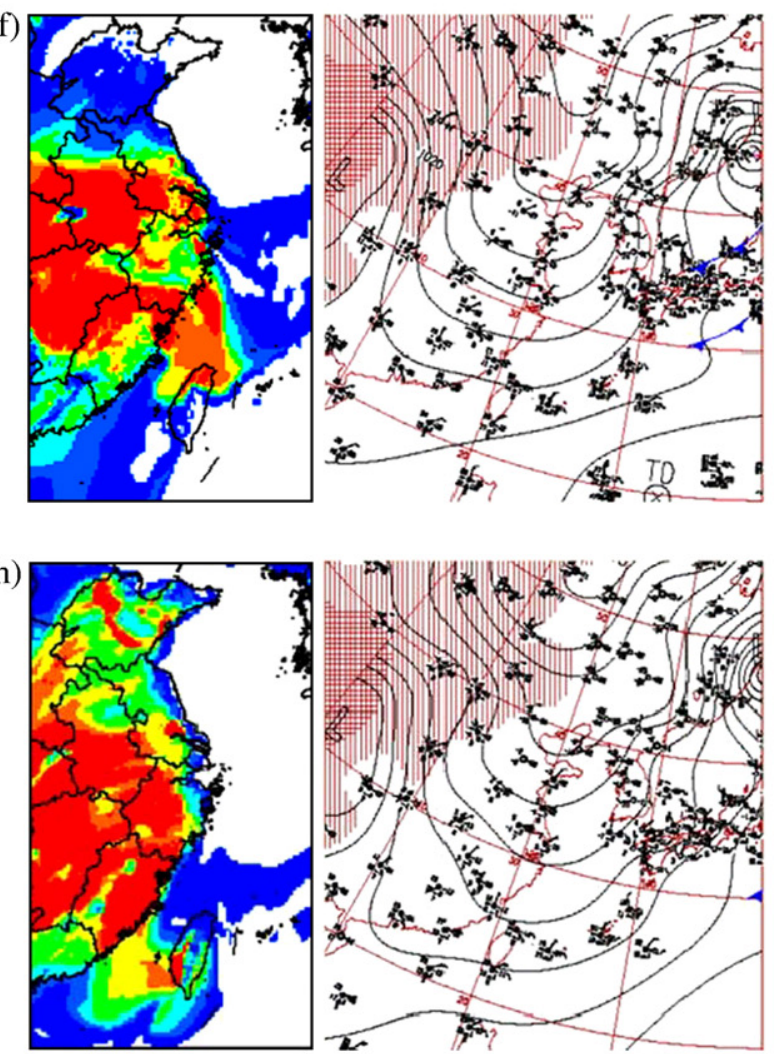

Fig. 2-Simulated near-surface $\mathrm{PM}_{2.5}$ concentration of domain 2 and surface weather map (produced by JMA, Japan Meteorology Agency, http://wwww.jma.go.jp/jp/g3/) in December 2004. (a) 08:00 of day19th, (b) 14:00 of day 19th, (c) 20:00 of day 19th, (d) 02:00 of day 20th, (e) 08:00 of day 20th, (f) 14:00 of day 20th, (g) 20:00 of day 20th, and (h) 02:00 of day 21st. 


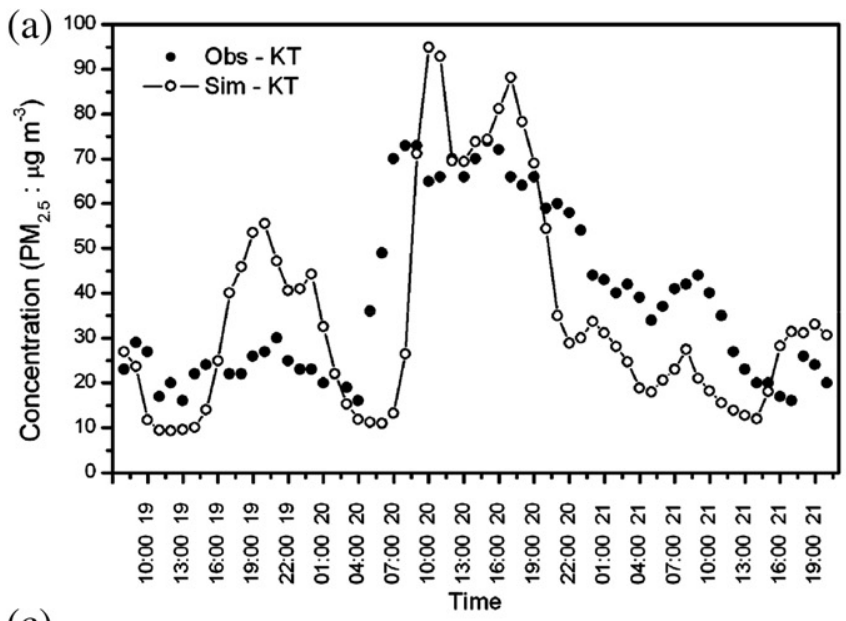

(c)

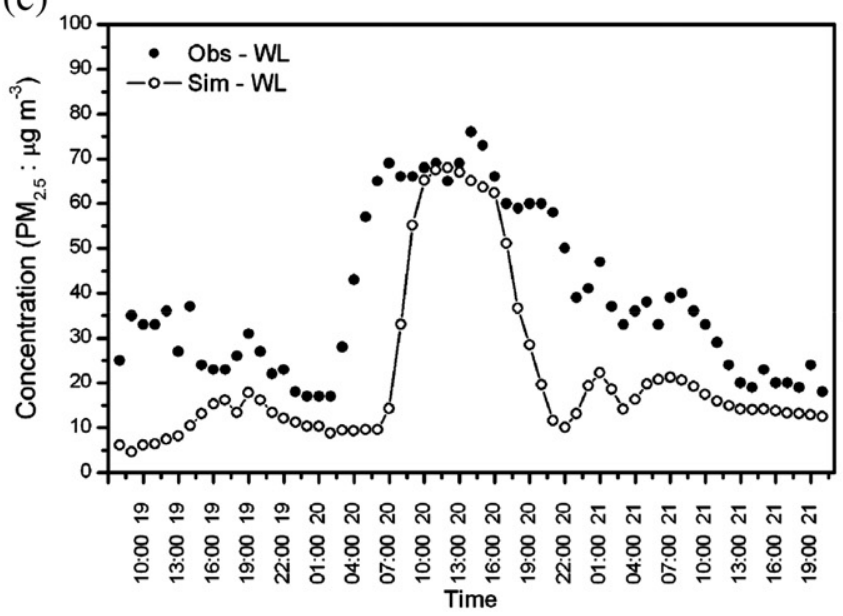

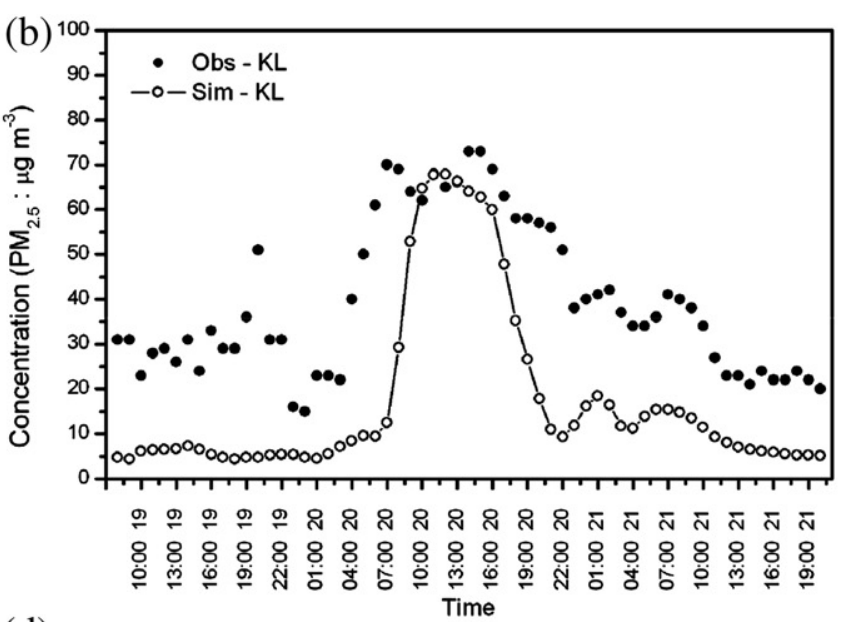

(d)

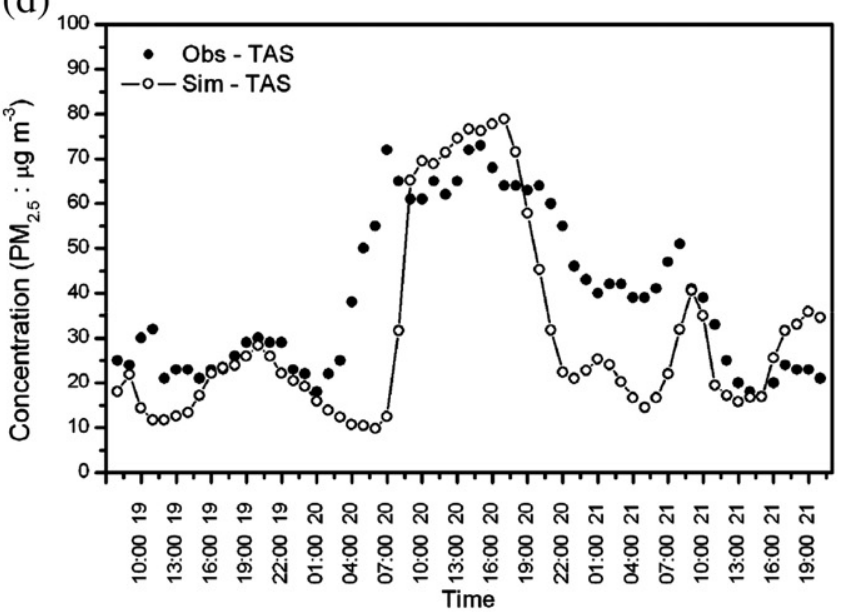

Fig. 3-Comparisons of ground observation (Obs) and model simulation (Sim) at the (a) KT site, (b) KL site, and (c) WL site for $\mathrm{PM}_{2.5}$, and at the TAS site for (d) $\mathrm{PM}_{2.5}$, (e) $\mathrm{PM}_{2.5}$ sulfate, (f) $\mathrm{PM}_{2.5}$ nitrate, (g) $\mathrm{PM}_{2.5}$ OC, and (h) $\mathrm{PM}_{2.5} \mathbf{E C}$ concentrations.

and the consistency between $\mathrm{PM}_{2.5}$ and $\mathrm{PM}_{2.5}$ sulfate indicated that they were both contributed from long-range transport. In contrast, long-range transport had little effect on $\mathrm{PM}_{2.5}$ nitrate except for the sporadic peaks from local pollution. The other deviation between model simulation and observation was seen from the high $\mathrm{PM}_{2.5}$ OC and $\mathrm{PM}_{2.5}$ EC at the TAS site estimated from model simulation but low yields in actual observation. The low $\mathrm{PM}_{2.5}$ carbons from measurements, however, might be due to the malfunction of the carbon monitor at the TAS site as detailed in the quality assurance report for the site (TWEPA, 2006b). The collocated manual samples for the 12-hour averages of $\mathrm{PM}_{2.5}$ OC and $\mathrm{PM}_{2.5} \mathrm{EC}$ were at 10-20 and 4-7 $\mu \mathrm{g} \mathrm{m}^{-3}$, respectively (TWEPA, 2006b). These results revealed that the simulated $\mathrm{PM}_{2.5} \mathrm{OC}$ and $\mathrm{PM}_{2.5}$ EC in this study may not differ much from the real numbers. However, further studies in the near future are required in order to verify the consistency between simulation and measurement.

Carmichael et al. (2003) evaluated the Asian emission estimations in 2000 (Streets et al., 2003) and concluded that light alkanes, $\mathrm{CO}$, ethylene, $\mathrm{SO}_{2}$, and $\mathrm{NO}_{\mathrm{X}}$ all performed well, but large uncertainty still existed in NMHC and BC. Tan et al. (2004) used air quality model to assess the Asian emission database and suggested that $\mathrm{CO}$ and particulate carbon should be increased by 50 and 60-90\%, respectively. In this study, the multiplication of Asian source emissions of 2001 with a yearly growth factor for the year of 2004 was acceptable since the simulation results fitted well with the observations, both quantitatively and qualitatively.

\subsection{The evolution of aerosol chemical components during} air mass transport

The researchers selected the time at 16:00 of December 20th for the TAS site and traced its near-surface backward trajectory hour by hour with marked numbers as shown in Fig. 4(a). Fig. 4(b)-(g) characterize the time evolution of the simulated precursor gases and $\mathrm{PM}_{2.5}$ components along the trajectory path of $\mathrm{PM}_{2.5}$ plume as shown in Fig. 4(a). Various pollutant concentrations at each time step were an integration of advection, diffusion, emission, chemical reaction, and scavenge in the modelling calculation. Therefore, pollutant concentrations at each time step cannot be easily interpolated between the preceding and posterior time steps especially when the $\mathrm{PM}_{2.5}$ plume comes near land or encounters a strong convective system. The variations of precursor gases and 


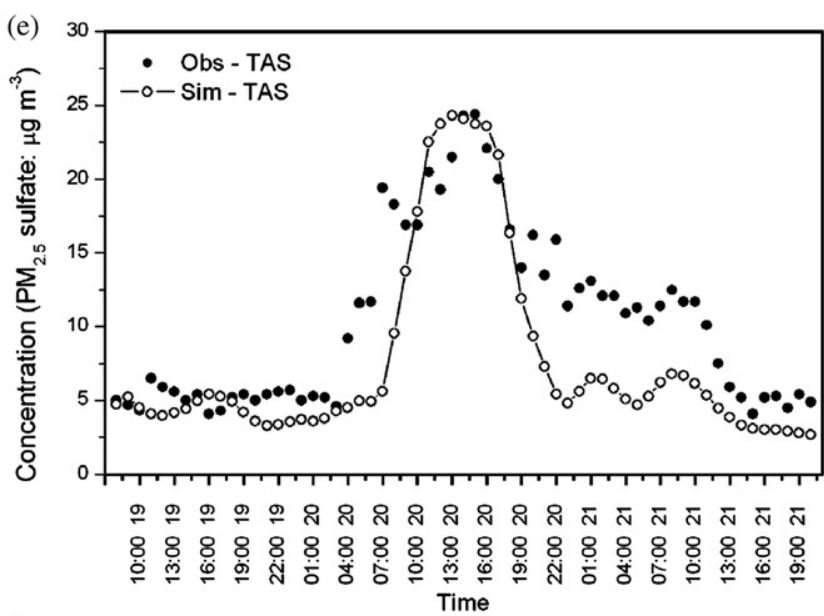

(g)

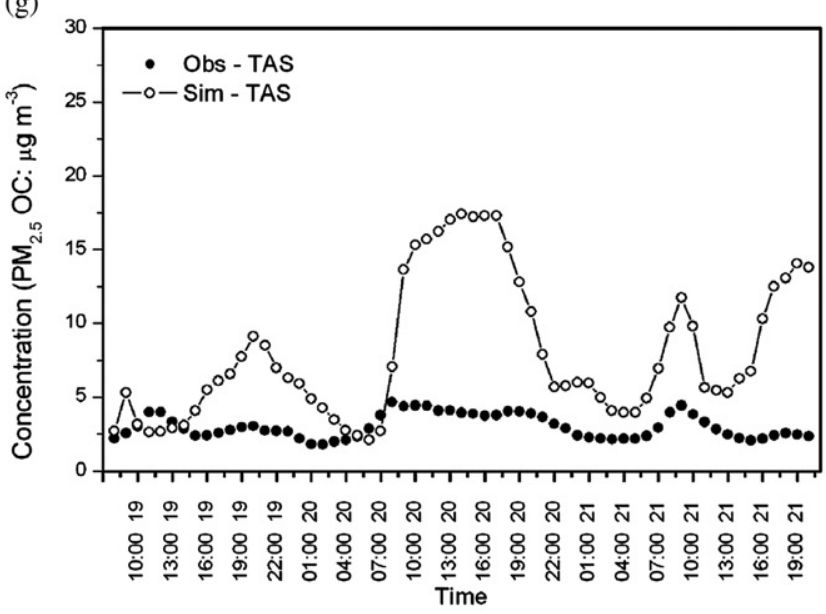

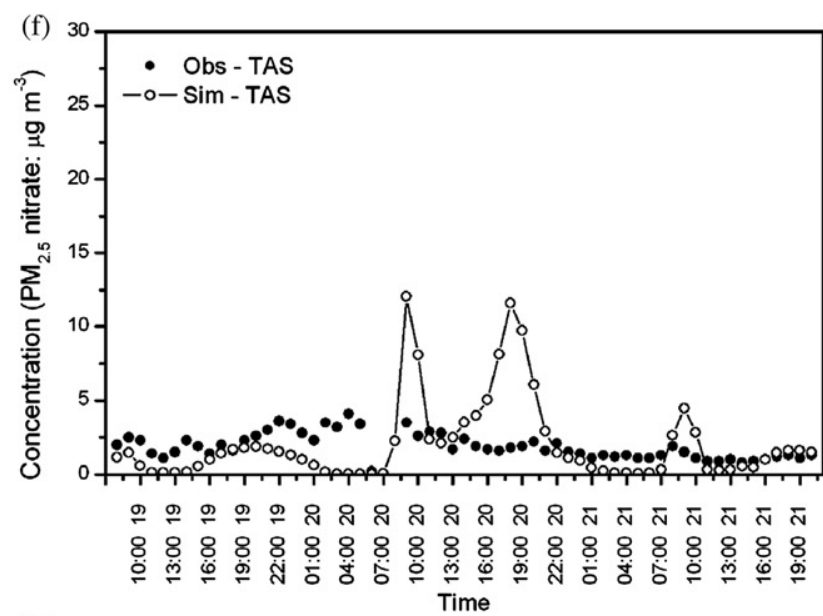

(h)

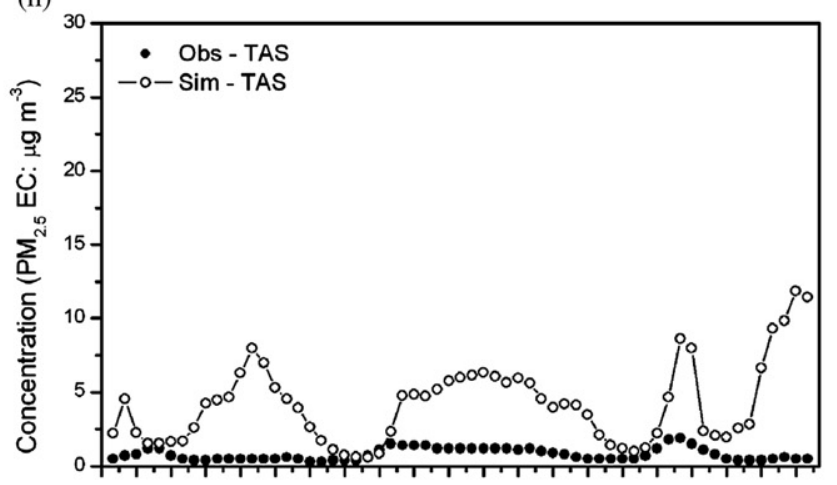

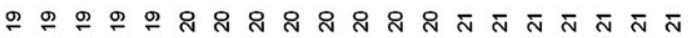

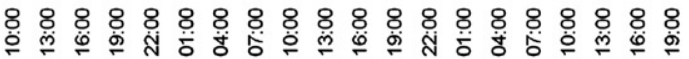
Time

Fig. 3 (continued)

$\mathrm{PM}_{2.5}$ components in the moving $\mathrm{PM}_{2.5}$ plume were differed from those shown in Fig. 4(b)-(g). The $\mathrm{PM}_{2.5}$ level was over $160 \mu \mathrm{g} \mathrm{m}^{-3}$ when the $\mathrm{PM}_{2.5}$ plume was around Shanghai, but it decreased to below $100 \mu \mathrm{g} \mathrm{m}^{-3}$ after the moving of $\mathrm{PM}_{2.5}$ plume to the East China Sea due to the mix of clean ocean air. The decline of $\mathrm{PM}_{2.5}$ level over the East China Sea was snail-paced, indicating that the air mass moving southwardly was in the stable stratified layer of the lower atmosphere.

\subsection{1. $\quad \mathrm{PM}_{2.5}$ nitrate during air mass transport}

The percentage variation of $\mathrm{PM}_{2.5}$ components at each time step along with the path of moving $\mathrm{PM}_{2.5}$ plume is shown in Fig. 4(b). Strikingly, the percentage of $\mathrm{PM}_{2.5}$ nitrate in $\mathrm{PM}_{2.5}$ decreased from 16\%-25\% in the area of Shanghai and Yangzi River outlet to $1 \%$ around the waters north to Taiwan. Assuming that the main species in $\mathrm{PM}_{2.5}$ nitrate is $\mathrm{NH}_{4} \mathrm{NO}_{3}$, the researchers then attributed the decrease of $\mathrm{PM}_{2.5}$ nitrate to two reasons (Stelson and Seinfeld, 1982). First, temperature increased during long-range transport as the $\mathrm{PM}_{2.5}$ plume moves from a high latitude to a low latitude area (Fig. 4(c)), causing volatile $\mathrm{PM}_{2.5}$ nitrate to evaporate from aerosol phase into gas phase $\left[\mathrm{NH}_{4} \mathrm{NO}_{3}(\mathrm{~s}) \leftrightarrow \mathrm{NH}_{3}(\mathrm{~g})+\mathrm{HNO}_{3}(\mathrm{~g})\right]$. Second, low $\mathrm{HNO}_{3}$ or $\mathrm{NH}_{3}$ (Fig. 4(d)) concentration made the product of $\left[\mathrm{HNO}_{3}\right]\left[\mathrm{NH}_{3}\right]$ lower than its equilibrium state, and therefore, the nitrate tended to stay in the gas phase.
The variations of $\mathrm{PM}_{2.5}$ nitrate, $\mathrm{NO}_{\mathrm{X}}, \mathrm{HNO}_{3}$, and $\mathrm{NH}_{3}$ concentrations at each time step are shown in Fig. 4(d). In the afternoon of December 19th, the NO emitted from sources in the Shanghai area should have reacted with $\mathrm{RO}_{2}$ or $\mathrm{HO}_{2}$ radical or $\mathrm{O}_{3}$ to form $\mathrm{NO}_{2}$. Thus, $\mathrm{NO}_{\mathrm{X}}$ was mainly composed of $\mathrm{NO}_{2}$, which reacted with $\mathrm{OH}$ rapidly and formed $\mathrm{HNO}_{3}$ in the daytime (Waston et al., 1994). Subsequent reaction of $\mathrm{HNO}_{3}$ with $\mathrm{NH}_{3}$ formed $\mathrm{NH}_{4} \mathrm{NO}_{3}$. During the transport of $\mathrm{PM}_{2.5}$ plume from Shanghai to the Yangzi River outlet, $\mathrm{PM}_{2.5}$ nitrate and $\mathrm{NO}_{\mathrm{X}}$ mixing ratio were high. As $\mathrm{NO}_{\mathrm{X}}$ varied greatly between $30-70 \mathrm{ppb}$, the contribution from local emissions could not be wiped out. Meantime, $\mathrm{PM}_{2.5}$ nitrate was noticeably high, varying between 19 to $29 \mu \mathrm{g} \mathrm{m}^{-3}$, which showed that $\mathrm{NH}_{3}$ emissions from local sources were abundant. The ambient $\mathrm{NH}_{3}$ concentration was 2-6 ppb, it varied roughly with $\mathrm{PM}_{2.5}$ nitrate concentration and remained nearly $0 \mathrm{ppb}$ most of the time. Also, $\mathrm{HNO}_{3}$ concentration was low. This implied that most of the precursor gases had been converted into aerosol nitrate. As the $\mathrm{PM}_{2.5}$ plume moved southwardly, $\mathrm{PM}_{2.5}$ nitrate concentration decreased to $10 \mu \mathrm{g} \mathrm{m}^{-3}$ at 19:00 of December 19th, stayed constant until 01:00 of December 20th, and declined further down to as low as $1 \mu \mathrm{g} \mathrm{m}^{-3}$ in the morning of December 20th. The quasi steady-state $\mathrm{PM}_{2.5}$ nitrate was probably contributed from liquid aerosol nitrate through the reaction between $\mathrm{N}_{2} \mathrm{O}_{5}$ and $\mathrm{H}_{2} \mathrm{O}$ as the two reactants were both high in the nighttime (see Fig. 4(c) and (e)) (Waston et al., 1994). Aerosol NO $\mathrm{N}_{3}^{-}$ 
(a)

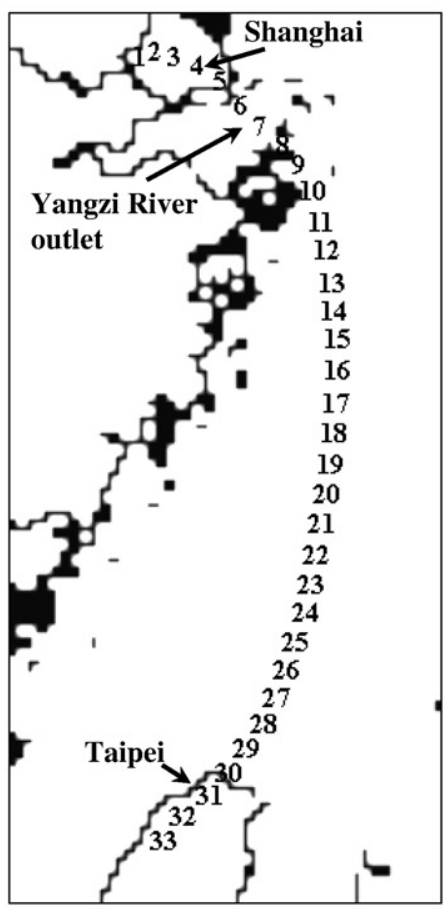

(b)
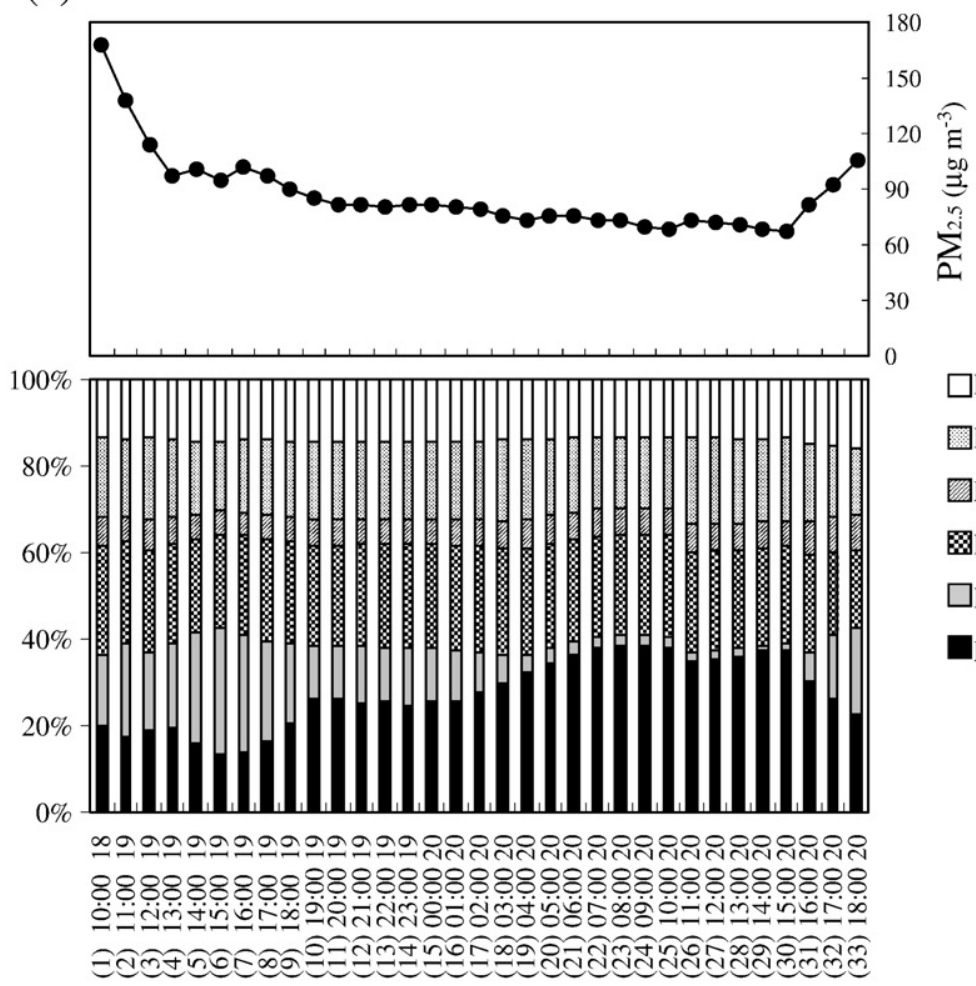

$\square \mathrm{PM}_{2.5}$ ammonium

$\square \mathrm{PM}_{2.5}$ others

$\square \mathrm{PM}_{2.5} \mathrm{EC}$

खPM $\mathrm{PM}_{2.5} \mathrm{OC}$

$\square \mathrm{PM}_{2.5}$ nitrate

$\mathrm{PM}_{2.5}$ sulfate

Fig. 4- $\mathrm{PM}_{2.5}, \mathrm{PM}_{2.5}$ chemical components, and precursor gases went along with the back trajectory path (a) the hourly back trajectory path, (b) the percentage of $\mathrm{PM}_{2.5}$ chemical components in $\mathrm{PM}_{2.5}$ mass concentration, (c) relative humidity and temperature, (d) $\mathrm{PM}_{2.5}$ nitrate, $\mathrm{NO}_{\mathbf{x}}, \mathrm{HNO}_{3}$, and $\mathrm{NH}_{3}$, (e) ozone, $\mathrm{PAN}, \mathrm{N}_{2} \mathrm{O}_{5}$, and $\mathrm{NO}_{3}$ radical, (f) $\mathrm{PM}_{2.5}$ sulfate, $\mathrm{PM}_{2.5}$ ammonium, $\mathrm{SO}_{2}, \mathrm{NH}_{3}, \mathrm{H}_{2} \mathrm{O}$, and $\mathrm{H}_{2} \mathrm{O}_{2}$, (g) $\mathrm{PM}_{2.5} \mathrm{OC}, \mathrm{PM}_{2.5} \mathrm{EC}, \mathrm{PM}_{2.5}$ OC/EC ratio, and vOCs (volatile organic carbons).

concentration was observed to be low in the fine mode when it was transported in Asian dust (Kim and Park (2001)). This validated the fact that the life span of $\mathrm{NO}_{3}^{-}$in the fine mode of ambient aerosols is very short. Interestingly, $\mathrm{HNO}_{3}$ concentration escalated, while $\mathrm{PM}_{2.5}$ nitrate actually declined. This indicates that the temperature increase caused volatile $\mathrm{NH}_{4} \mathrm{NO}_{3}$ to dissociate into $\mathrm{HNO}_{3}$ and $\mathrm{NH}_{3}$ (Stelson and Seinfeld, 1982) when the $\mathrm{PM}_{2.5}$ plume moved from a high latitude to a low latitude area. 
(c)

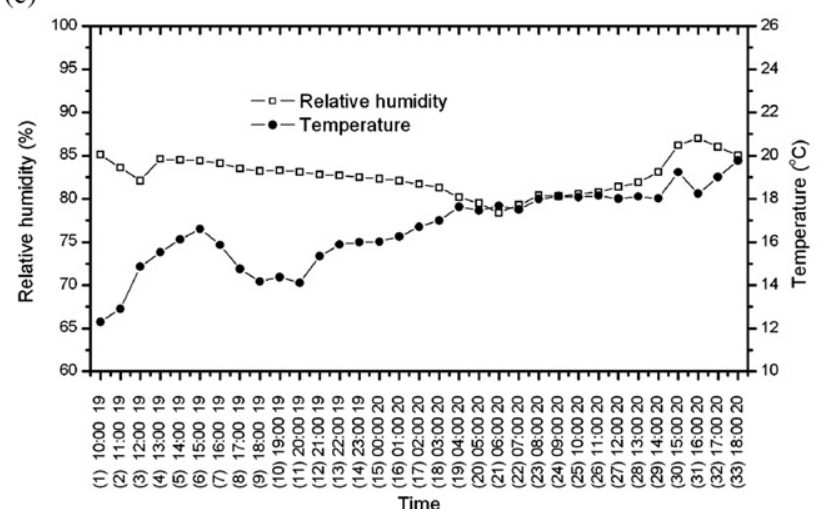

(e)

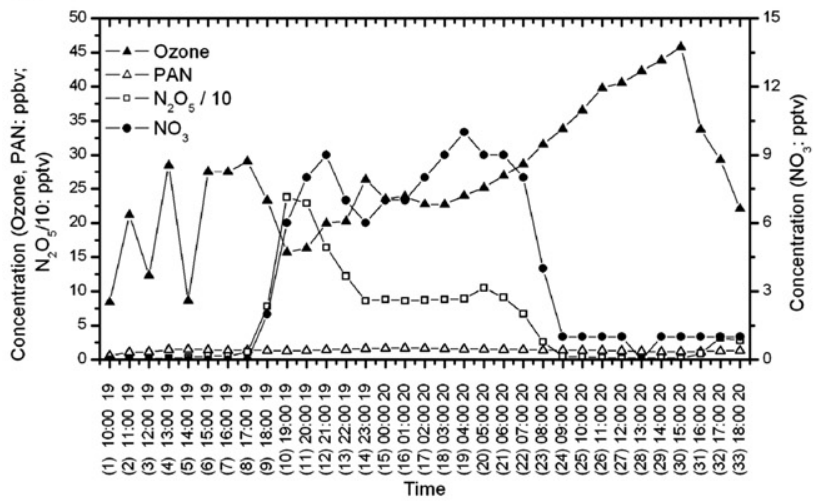

(d)

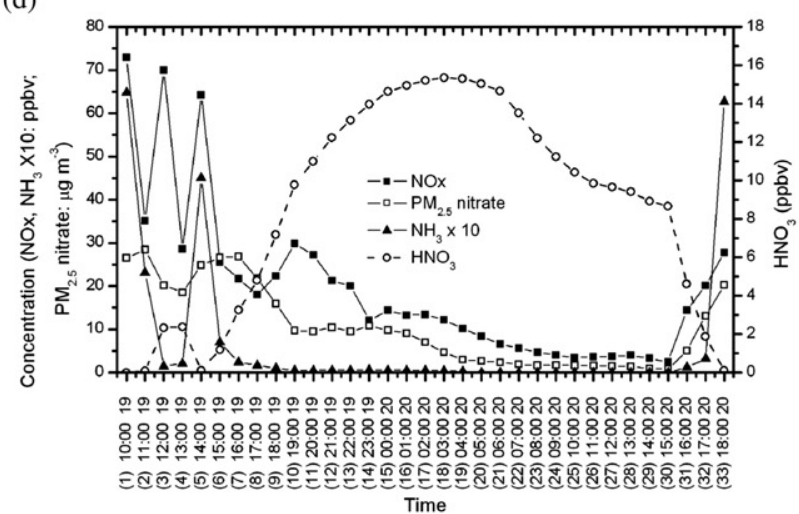

(f)

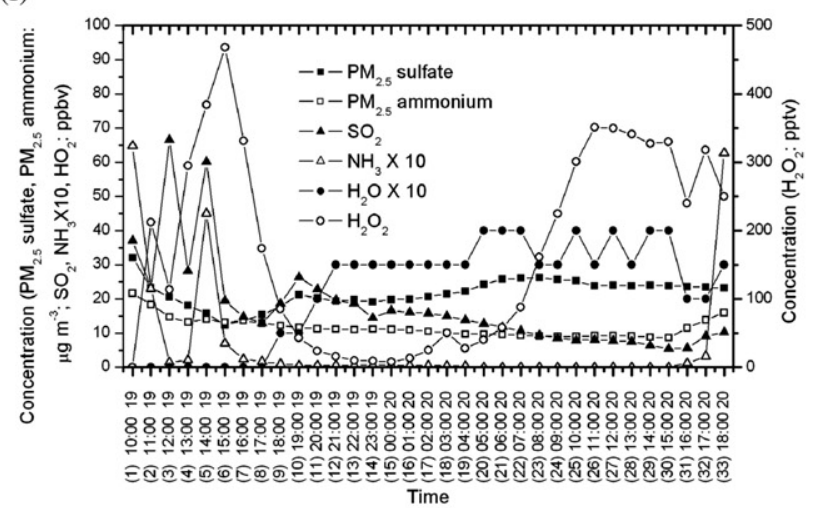

(g)

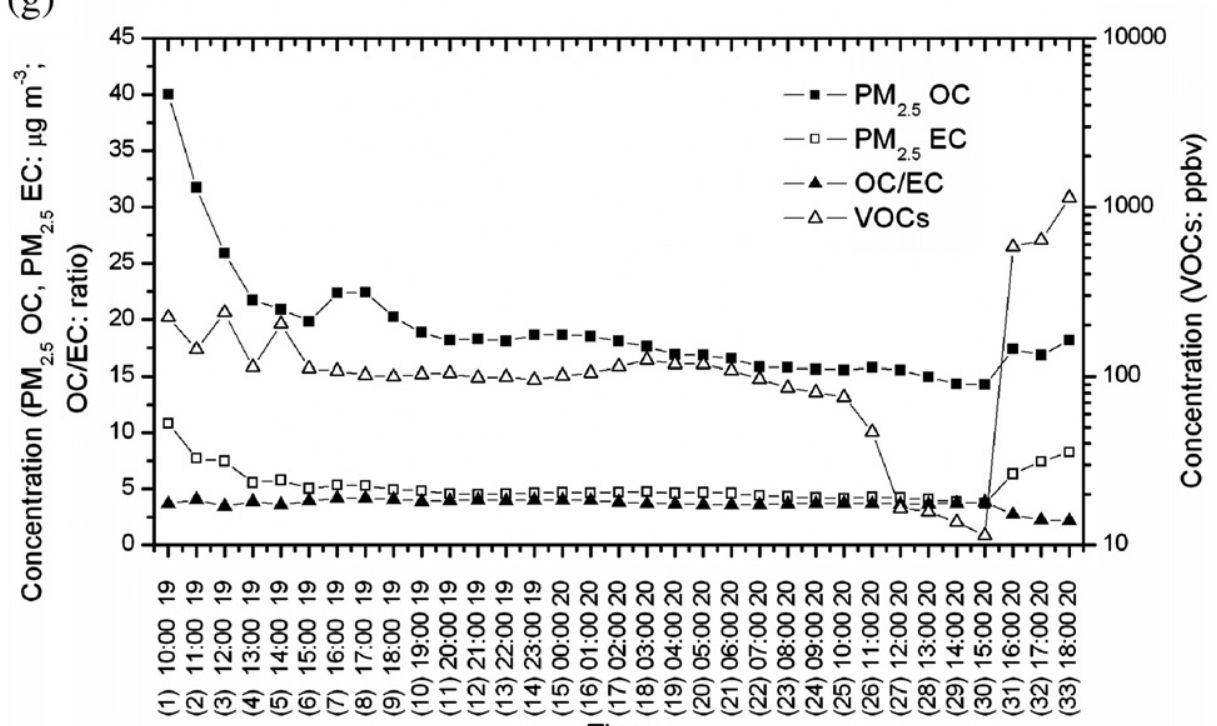

Time

Fig. 4 (continued)

Similarly in Hong Kong, the Zhuang et al.'s (1999a,b) study showed that the transport of $\mathrm{NH}_{4} \mathrm{NO}_{3}$ in the fine particulate mode from southern China was unstable. $\mathrm{NH}_{4} \mathrm{NO}_{3}$ tends to dissociate into $\mathrm{NH}_{3}$ and $\mathrm{HNO}_{3}$ at a temperature above $20{ }^{\circ} \mathrm{C}$ and a relative humidity between 40 and $75 \%$. Therefore, it is reasonable to infer that the simulated $\mathrm{PM}_{2.5}$ nitrate concentration decreased during the southward long-range transport in this study. The released $\mathrm{HNO}_{3}$ might react with sea salt to form $\mathrm{NaNO}_{3}$ and $\mathrm{HCl}$. In view of this, Yao et al. (2003) and Shimohara et al. (2001) analyzed the samples in Hong Kong and Japan, respectively, and they both found that nitrate evaporated from aerosol phase to gas phase during longrange transport. Part of the evaporated aerosol nitrate remained as gaseous $\mathrm{HNO}_{3}$, while the rest could have reacted with coarse mode $\mathrm{NaCl}$ or $\mathrm{CaCO}_{3}$ to form $\mathrm{NaNO}_{3}$ and $\mathrm{Ca}$ $\left(\mathrm{NO}_{3}\right)_{2}$. Similar conclusions were drawn by experiments in 
TRACE-P campaign (Jordan et al., 2003; Talbot et al., 2003; Dibb et al., 2003).

Since the reaction of sea salt with $\mathrm{HNO}_{3}$ was not included in CMAQ v4.4, and $\mathrm{NaCl}$ emission was not included in emission input files, simulated $\mathrm{HNO}_{3}$ in this study might have been overestimated. The overestimated $\mathrm{HNO}_{3}$ led to overestimated $\mathrm{PM}_{2.5}$ nitrate peaks simulated at the TAS site since there is a local $\mathrm{NH}_{3}$ emission in the Taipei basin (Fig. 3 (f)). Besides, $\mathrm{O}_{3}$ remained nearly constant at night on December 19th (Fig. 4(e)) and increased on the next day since there was little NO in the moving $\mathrm{PM}_{2.5}$ plume. Also, 1.2 to $1.7 \mathrm{ppb}$ of PAN (Fig. 4(e)) was produced in the $\mathrm{PM}_{2.5}$ plume, , which had a similar variation cycle as $\mathrm{HNO}_{3}$ since they were both converted from $\mathrm{NO}_{\mathrm{X}}$.

\subsection{2. $\quad \mathrm{PM}_{2.5}$ sulfate during air mass transport}

Along the path of moving $\mathrm{PM}_{2.5}$ plume, the evolution of $\mathrm{PM}_{2.5}$ sulfate, $\mathrm{PM}_{2.5}$ ammonium, $\mathrm{SO}_{2}, \mathrm{NH}_{3}$, and $\mathrm{H}_{2} \mathrm{O}_{2}$ is shown in Fig. 4(f). $\mathrm{PM}_{2.5}$ sulfate decreased gradually but was still above $15 \mu \mathrm{g} \mathrm{m}^{-3}$ when the $\mathrm{PM}_{2.5}$ plume moved from Shanghai to the Yangzi River outlet. This was due to the reaction between $\mathrm{H}_{2} \mathrm{SO}_{4}$ and $\mathrm{NH}_{3}$. The $\mathrm{H}_{2} \mathrm{SO}_{4}$ was converted from $\mathrm{SO}_{2}$, which was varied between 16 and $66 \mathrm{ppb}$ during this period. Meanwhile, $\mathrm{NH}_{3}$ plummeted to almost $0 \mathrm{ppb}$ probably due to the reactions with abundant $\mathrm{H}_{2} \mathrm{SO}_{4}$ and $\mathrm{HNO}_{3}$ (see Section 4.4.1). The $\mathrm{PM}_{2.5}$ sulfate gradually increased in the early morning of December 20th through the reaction of $\mathrm{NH}_{3}$ (evaporated from $\mathrm{PM}_{2.5}$ nitrate) with $\mathrm{H}_{2} \mathrm{SO}_{4}$ and formed $\left(\mathrm{NH}_{4}\right)_{2} \mathrm{SO}_{4}$ or $\mathrm{NH}_{4} \mathrm{HSO}_{4}$ (Seinfeld and Pandis, 1998). This conjecture can be evidenced by the increase of $\mathrm{H}_{2} \mathrm{O}_{2}$ contributed from the reaction of selfreacted $\mathrm{HO}_{2}$ radical or with water (Kleinman, 1991; and relative humidity at around $80 \%$ in Fig. $4(\mathrm{c})$ ) and the slight increase of $\mathrm{PM}_{2.5}$ sulfate in the early morning of December 20th as shown in Fig. 4(f). In the daytime of December 20th, less $\mathrm{PM}_{2.5}$ sulfate was formed since $\mathrm{PM}_{2.5}$ nitrate was quite low, and less nitrate evaporated to release $\mathrm{NH}_{3}$. Therefore, $\mathrm{PM}_{2.5}$ sulfate slightly decreased due to the dilution of air. During the transport, the $\mathrm{PM}_{2.5}$ sulfate rose from $16-19 \%$ in Shanghai to $35 \%$ at the northern tip of Taiwan in Fig. 4(b).

Similarly in Hong Kong, Pathak et al. (2003) found that $42 \%$ of $\mathrm{PM}_{2.5}$ water-soluble ions accounted for $\mathrm{SO}_{4}^{2-}$ in spring 2000 and 2001; Ho et al. (2003) observed that $\mathrm{PM}_{2.5}$ sulfate occupied $27 \%$ of $\mathrm{PM}_{2.5}$ from November 2000 to February 2001. In Japan, Shimohara et al. (2001) found that nss- $\mathrm{SO}_{4}^{2-}$ occupied $22 \%$ of the total ions in the field observation conducted in January and December 1997. These leave no doubt that sulfate is a major tracer of long-range transport plume from the Asian Continent during cold seasons.

\subsection{3. $\mathrm{PM}_{2.5}$ ammonium during air mass transport}

From aircraft observation around the Western Pacific Ocean in the TRACE-P campaign, Jordan et al. (2003) state that in the longrange transport plume, there should be enough nss- $\mathrm{SO}_{4}^{2-}$ to react with $\mathrm{NH}_{4}^{+}$. This implies that $\mathrm{NH}_{3}$ evaporating from ammonium nitrate would be available to transfer sulfuric acid into ammonium sulfate during plume transport. Although the $\mathrm{PM}_{2.5}$ ammonium concentration was nearly $20 \mu \mathrm{g} \mathrm{m}^{-3}$ in Shanghai, and it gradually decreased to $9 \mu \mathrm{g} \mathrm{m}^{-3}$ in Taipei (Fig. 4(f)), the percentage of $\mathrm{PM}_{2.5}$ ammonium remained about $13 \%$ as shown in Fig. 4(b). It is known that $\mathrm{PM}_{2.5}$ ammonium could be in the form of $\mathrm{NH}_{4} \mathrm{NO}_{3}$ or $\left(\mathrm{NH}_{4}\right)_{2} \mathrm{SO}_{4}$ or $\mathrm{NH}_{4} \mathrm{HSO}_{4}$ in the source area. In TRACE-P campaign, Dibb et al. (2003) suggested that $\mathrm{NH}_{4} \mathrm{HSO}_{4}$ was the major type of aerosol sulfate when the plume was near the Asian Continent. The evaporated $\mathrm{NH}_{3}$ from $\mathrm{NH}_{4} \mathrm{NO}_{3}$ on the path of long-range transport could then react with $\mathrm{H}_{2} \mathrm{SO}_{4}$ to form $\left(\mathrm{NH}_{4}\right)_{2} \mathrm{SO}_{4}$ or $\mathrm{NH}_{4} \mathrm{HSO}_{4}$ when the plume moved closer to Taiwan. This accounted for the constant percentage of $\mathrm{PM}_{2.5}$ ammonium during plume transport in this study.

4.4.4. $\mathrm{PM}_{2.5}$ carbonaceous content during air mass transport In Fig. 4(g), VOCs fluctuated between 110 and 240 ppb as the $\mathrm{PM}_{2.5}$ plume moved from Shanghai to the outlet of the Yangzi River in the afternoon of December 19th. This can be attributed to the variations of source emissions. The percentage of $\mathrm{PM}_{2.5}$ OC in $\mathrm{PM}_{2.5}$ plume only slightly decreased from $22-24 \%$ in Shanghai to $21 \%$ near Taiwan. Meanwhile, the percentage of $\mathrm{PM}_{2.5}$ EC remained nearly the same at $6 \%$ of $\mathrm{PM}_{2.5}$. Along the transport path from Shanghai to the outlet of the Yangzi River and to the northern tip of Taiwan, $\mathrm{PM}_{2.5}$ OC did not decrease much faster than $\mathrm{PM}_{2.5}$ EC to result in the decrease of OC/EC ratio, which remained nearly constant at 3.7 (see Fig. 4(g)) over East China Sea. Lim et al. (2003), however, mentioned that there are two reasons for the decrease in OC/EC ratio during plume transport. First, EC is not as semi-volatile as OC, which makes it stable during the transport. Second, OC contains water-soluble organic carbon, which may decrease in the process of in-cloud scavenging. In addition, EC is hydrophobic and is less influenced by cloud or fog. In the current version of CMAQ model used in this study, the second mechanism is not included. Meanwhile, the temperature effect on the evolution of secondary organic aerosol is still uncertain in air quality modelling (Pun et al. (2003)). As the ratio of OC/EC is high but stable, the researchers tend to think that there was formation of secondary organic aerosol that compensated for the loss due to evaporation during long-range transport. The simulated $\mathrm{PM}_{2.5}$ OC, however, was higher than the observed value at the TAS site. The deviation might be due to the overestimation of the Asian emission database or the aerosol module in the CMAQ model or the underestimation of observations due to instrumental problem. However, the investigation of the cause is outside the scope of the study.

Finally, it is noted that the model simulation during the study period shows $\mathrm{PM}_{2.5}$ mass level, sulfate, nitrate, organic carbon, and elemental carbon with mean value at $46.1 \mu \mathrm{g} \mathrm{m}^{-3}, 12.7 \mu \mathrm{g}$ $\mathrm{m}^{-3}, 3.6 \mu \mathrm{g} \mathrm{m}^{-3}, 10.2 \mu \mathrm{g} \mathrm{m}^{-3}$, and $3.9 \mu \mathrm{g} \mathrm{m}^{-3}$, respectively. These values of aerosol components are very close to those of HPP weather pattern at the TAS site in Table 1 except for $\mathrm{PM}_{2.5}$ organic carbon. However, only one run of model simulation can not support the percentages of $\mathrm{PM}_{2.5}$ nitrate, sulfate, elemental carbon, and other aerosol components transferred from continental China on a general basis. More model simulations need to be done to represent the overall situation.

\section{Conclusions}

The evolution of aerosol mass and the associated chemical components transported from Asian Continent to Taiwan from 19 to 20 December 2004 was successfully simulated using CMAQ model in this study. Air masses transported a great 
quantity of $\mathrm{PM}_{2.5}$ southwardly to influence the air quality in Taipei during this event when the Asian high-pressure ridge stretched to Taiwan. Although the arrival time of the simulated $\mathrm{PM}_{2.5}$ plume was four hours late compared to the recorded observation of the study, the variation of simulated $\mathrm{PM}_{2.5}$ concentration correlated well with this study's observation. Besides, the simulated and observed $\mathrm{PM}_{2.5}$ peak levels were close to each other. As to the time evolution of $\mathrm{PM}_{2.5}$ components in the long-range transport, the percentage of $\mathrm{PM}_{2.5}$ OC in $\mathrm{PM}_{2.5}$ decreased slightly from 22-24\% in Shanghai to $21 \%$ in Taipei. The percentage of $\mathrm{PM}_{2.5}$ nitrate in $\mathrm{PM}_{2.5}$, however, decreased from $16-25 \%$ in Shanghai to $1 \%$ right before the $\mathrm{PM}_{2.5}$ plume entered the Taipei basin. The great loss of volatile $\mathrm{PM}_{2.5}$ nitrate was probably due to temperature increase when the plume descended from a high latitude to a low latitude area and the re-equilibrium process between gas and aerosol phases. The percentages of $\mathrm{PM}_{2.5}$ ammonium and $\mathrm{PM}_{2.5}$ EC in $\mathrm{PM}_{2.5}$ remained nearly constant during transport. The $\mathrm{PM}_{2.5}$ sulfate, however, gradually increased as the plume transported from the Yangzi River outlet to Taiwan. This occurred through the reaction of $\mathrm{NH}_{3}$ (evaporated from $\mathrm{PM}_{2.5}$ nitrate) with $\mathrm{H}_{2} \mathrm{SO}_{4}$. The increase of $\mathrm{PM}_{2.5}$ sulfate resulted in a huge increment in $\mathrm{PM}_{2.5}$ sulfate percentage in $\mathrm{PM}_{2.5}$ from 1619 to $35 \%$. This study verified the reason of high $\mathrm{PM}_{2.5}$ sulfate percentage in $\mathrm{PM}_{2.5}$, which is commonly observed in Hong Kong, Japan, ACE-Asia, and TRACE-P for the Asian continental outflow over the Western Pacific Ocean.

\section{Acknowledgements}

The researchers would like to express their gratitude to the Taiwan National Science Council (NSC 93-2111-M-008-018AGC) and the University of Tennessee at Knoxville for providing financial support to this study. They are also grateful to Dr. David Streets for providing the required data from the Asian emissions inventory. The researchers likewise acknowledge the contribution of the U.S. NCEP (National Centers for Environmental Prediction), DBAR (Data Bank of Atmospheric Research, managed by the Department of Atmospheric Sciences, National Taiwan University), and Taiwan Environmental Protection Administration for the atmospheric monitoring data used in this study.

\section{R E F E R E N C E S}

Berntsen TK, Karlsdottir S, Jaffe DA. Influence of Asian emissions on the composition of air reaching the North Western United States. Geophys Res Lett 1999;26:2171-4.

Borge R, Lumbreras J, Vardoulakis S, Kassomenos P, Rodríguez E. Analysis of long-range transport influences on urban PM10 using two-stage atmospheric trajectory clusters. Atmos Environ 2007;41:4434-50.

Byun, D.W., Ching, J.K.S. Science Algorithms of the EPA MODELS-3 Community Multiscale Air Quality (CMAQ) Modeling System; EPA/600/R-99/030. Washington, DC: Office of Research and Development, U. S. Environmental Protection Agency; 1999.

Carmichael GR, Ferm M, Adhikary S, Ahmed J, Mohan M, Hong MS, et al. Observed regional distribution of sulphur dioxide in Asia,
Special issues for the Acid Rain '95 Conference. Water Air Soil Pollut 1995;85:2289-94.

Carmichael GR, Tang Y, Kurata G, Uno I, Streets DG, Thongboonchoo N, et al. Evaluating regional emission estimates using the TRACE-P observations. J Geophys Res 2003;108(D21):8810. doi:10.1029/2002JD003116.

Chan CC, Hwang JS, Chen WC, Wang JL, Su DC, Chang HL. The influence of dust storm from Mainland China on Taiwanese resident. Dust storm academic workshop, Taipei, Taiwan; 2000. 29-30 June.

Chan CY, Xu XD, Li YS, Wong KH, Ding GA, Chan LY, et al. Characteristics of vertical profiles and sources of $\mathrm{PM}_{2.5}, \mathrm{PM}_{10}$ and carbonaceous species in Beijing. Atmos Environ 2005;39:5113-24.

Chang KH, Jeng FT, Tsai YL, Lin PL. Modeling of long-range transport on Taiwan's acid deposition under different weather conditions. Atmos Environ 2000;34:3281-95.

Chuang MT, Chiang PC, Chan CC, Wang CF, Chang YY, Lee CT. The effects of synoptical weather pattern and complex terrain on the formation of aerosol events in the greater Taipei area. Sci Total Environ 2008;399:128-46. doi:10.1016/j. scitotenv.2008.01.051.

Chung YS, Kim TK, Kim KH. Temporal variation and cause of acidic precipitation from a monitoring network in Korea. Atmos Environ 1996;30:2429-35.

Dibb JE, Talbot RW, Scheuer EM, Seid G, Avery MA, Singh HB. Aerosol chemical composition in Asian continental outflow during the TRACE-P campaign: Comparison with PEM-West B. J Geophys Res 2003;108(D21):8815. doi:10.1029/ 2002JD003111.

Farrell AE, Keating TJ. Transboundary environmental assessment: Lessons from OTAG. Environ Sci Technol 2002;36:2537-44.

Fu JS, Yeh FL, Chien HC, Carey RJC, Chuang MT. Air quality modelling - An investigation of the merits of trans-boundary air pollution from continents to small islands. Int J Environ Technol Manage (in press).

Gery MW, Whitten GZ, Killus JP, Dodge MC. A photochemical kinetics mechanism for urban and regional scale computer modeling. J Geophys Res 1989;94:12925-56.

Grell. G.A., Dudhia, J., Stauffer, D.R., 1994: A description of the fifthgeneration Penn State/NCAR mesoscale model (MM5); NCAR/ TN-398+STR, NCAR Technical Note;1994. http://www.mmm. ucar.edu/mm5/mm5-home.html (last visit: November 29, 2007).

Grivas G, Chaloulakou A, Kassomenos P. An overview of the PM10 pollution problem, in the Metropolitan area of Athens, Greece. Assessment of controlling factors and potential impact of long range transport. Sci Total Environ 2008;389:165-77.

Hageman KJ, Simonich SL, Campbell DH, Wilson GR, Landers DH. Atmospheric deposition of current-use and historic-use pesticides in snow at national parks in the Western United States. Environ Sci Technol 2006;40:3174-80.

Han YJ, Holsen TM, Hopke PK, CheongJP, Kim H, Yi SM. Identification of source locations for atmospheric dry deposition of heavy metals during yellow-sand events in Seoul, Korea in 1998 using hybrid receptor models. Atmos Environ 2004;38:5353-61.

Hao J, Wang L. Improving urban air quality in China: Beijing case study. J Air Waste Manage Assoc 2005;55:1298-305.

Harrison RM, Yin J. Particulate matter in the atmosphere: which particle properties are important for its effects on health? Sci Total Environ 2000;249:85-101.

Heo, E., Feng, Y. Recent development of energy use in China at the industrial sector level. http://www.cenet.org.cn/cn/CEAC/ 2005in/zyhj011.doc;2005.

Ho KF, Lee SC, Chan CK, Yu JC, Chow JC, Yao XH. Characterization of chemical species in $\mathrm{PM}_{2.5}$ and $\mathrm{PM}_{10}$ aerosols in Hong Kong. Atmos Envriron 2003;37:31-9.

Holloway T, Levy II H, Carmichael G. Transfer of reactive nitrogen in Asia: development and evaluation of a source-receptor model. Atmos Environ 2002;36:4251-64. 
Houyoux, M., Vukovich, J. Updates to the Sparse Matrix Operator Kernel Emissions (SMOKE) modeling system and integration with Models-3, Presented at The Emissions Inventory : Regional Strategies for the Future Conference, J Air \& Waste Manage Assoc, Raleigh, NC; 1999. 26-28 October.

Ichikawa Y, Fujita S. An analysis of wet deposition of sulfate using a trajectory model for east Asia. Water Air Soil Pollut 1995;85:1927-32.

Jordan CE, Dibb JE, Anderson BE, Fuelberg HE. Uptake of nitrate and sulfate on dust aerosols during TRACE-P. J Geophys Res 2003;108(D21):8817. doi:10.1029/2022JD003101.

Kennedy KJ, Hinds WC. Inhalability of large solid particles. J Aerosol Sci Technol 2002;33:237-55.

Kim BG, Park SU. Transport and evolution of a winter-time Yellow sand observed in Korea. Atmos Environ 2001;35:3191-201.

Kitada, T., Tanaka, K. Simulated semi-global scale transport of $\mathrm{SO}_{2}$ and $\mathrm{SO}_{4}^{=}$from East Asia to the Northern Pacific in spring season: The role of low and high pressure systems. Air Pollution Modeling and Its Application IX. 445-454; 1992.

Kleinman LI. Seasonal dependence of boundary layer peroxide concentration: the low and high NOx regimes. J Geophys Res 1991;96:20721-33.

Koçak M, Mihalopoulos N, Kubilay N. Contributions of natural sources to high PM10 and PM2.5 events in the eastern Mediterranean. Atmos Environ 2007;41:3806-18.

Lee CT, Chuang MT, Chan CC, Cheng TJ, Hung SL. Aerosol characteristics from the Taiwan aerosol supersite in the Asian yellow-dust periods of 2002. Atmos Environ 2006;40:3409-18.

Lim HJ, Turpin BJ, Russell LM, Bates TS. Organic and elemental carbon measurements during ACE-Asia suggest a longer atmospheric lifetime for elemental carbon. Environ Sci Technol 2003;37:3055-61.

Lin TH. Long-range transport of yellow sand to Taiwan in Spring 2000: observed evidence and simulation. Atmos Environ 2001;35:5873-82.

Lin CY, Liu SC, Chou CC, Liu TH, Lee CT, Yuan CS, et al. Long-range transport of Asia dust and air pollutants to Taiwan. Terres Atmos Oceanic Sci 2005;15:759-84.

Liu CM, Young CY, Lee YC. Influence of Asia dust storms on air quality of Taiwan. Sci Total Environ 2006;368:884-97.

Nishikawa M, Hao Q, Morita M. Preparation and evaluation of certified reference materials for Asian mineral dust. Global Environ Res 2000;4:103-13.

Pathak RK, Yao X, Lau AKH, Chan CK. Acidity and concentrations of ionic species of $\mathrm{PM}_{2.5}$ in Hong Kong. Atmos Environ 2003;37:1113-24.

Pun BK, Wu SY, Seigneur C, Seinfeld JH, Griffin RJ, Pandis SN. Uncertainties in modeling secondary organic aerosols: three-dimensional modeling studies in Nashville/Western Tennessee. Environ Sci Technol 2003;37:3647-61.

Schwartz J, Dockery DW, Neas LM. Is Daily Mortaility Associated Specifically with Fine Particles? J Air Waste Manage Assoc 1996;46:927-39.

Seinfeld JH, Pandis SN. Atmospheric Chemistry and Physics: From Air Pollution to Climate Change. New York, NY: Wiley; 1998. p. 529-31.

Shimohara T, Oishi O, Utsunomiya A, Mukai H, Hatakeyama S, Sun-Eun J, et al. Characterization of atmospheric air pollutants at two sites in northern Kyushu, Japan-chemical form, and chemical reaction. Atmos Environ 2001;35:667-81.

Stelson AW, Seinfeld JH. Relative humidity and temperature dependence of the ammonium nitrate dissociation constant. Atmos Environ 1982;16:983-92.

Streets DG, Bond TC, Carmichael GR, Fernandes S, Fu Q He D, et al. An inventory of gaseous and primary aerosol emissions in Asia in the year 2000. J Geophys Res 2003;108(D21):8809. doi:10.1029/ 2002JD003093.

Talbot R, Dibb E, Scheuer E, Seid G, Russo R, Sandholm S, et al. Reactive nitrogen in Asian continental outflow over the western Pacific: results from NASA transport and chemical evolution over the Pacific (TRACE-P) airborne mission. J Geophys Res 2003;108(D20):8803. doi:10.1029/2002JD003129.

Tan Q, Chameides WL, Streets D, Wang T, Xu J, Bergin M, et al. An evaluation of TRACE-P emission inventories from China using a regrional model and chemical measurements. J Geophys Res 2004;109:D22305. doi:10.1029/2004JD005071.

TWEPA, Taiwan Environmental Protection Agency, Air pollutants emissions inventory updation management and air quality consumption plan - the second year, 2006a. EPA-95-FA11-03-D035 (in Chinese).

TWEPA, Taiwan Environmental Protection Agency, Operation and quality assurance of Aerosol supersite site and photochemical assessment site and data analysis project, $2006 \mathrm{~b}$. EPA-94-FA11-03-014 (in Chinese).

Wang C-C, Lee CT, Liu SC, Chen JP. Aerosol characterization at Taiwan's northern tip during ACE-Asia. Terres Atmos Oceanic Sci 2004;15:839-55.

Waston JG, Chow JC, Lurmann FW, Musarra SP. Ammonium nitrate, nitric acid, and ammonia equilibrium in wintertime Phoenix, Arizona. J Air Waster Manage Assoc 1994;44:405-12.

Yao X, Fang M, Chan CK. The size dependence of chloride depletion in the fine and coarse sea-salt particles. Atmos Environ 2003;37:743-51.

Zhuang H, Chan CK, Fang M, Wexler AS. Size distributions of particulate sulphate, nitrate, and ammonium at a coastal site in Hong Kong. Atmos Environ 1999a;33:843-53.

Zhuang H, Chan CK, Fang M, Wexler AS. Formation of nitrate and non-seasalt sulfate on coarse particles. Atmos Environ 1999b;33:4223-33. 